5. Hodžić A, Latrofa MS, Annoscia G, Alić A, Beck R, Lia RP, et al. The spread of zoonotic Thelazia callipaeda in the Balkan area. Parasit Vectors. 2014;7:352. http://dx.doi.org/10.1186/1756-33057-352

6. Mihalca AD, D'Amico G, Scurtu I, Chirilă R, Matei IA, Ionică AM. Further spreading of canine oriental eyeworm in Europe: first report of Thelazia callipaeda in Romania. Parasit Vectors. 2015;8:48. http://dx.doi.org/10.1186/s13071-015-0663-2

7. Tasić-Otašević S, Gabrielli S, Trenkić-Božinović M, Petrović A, Gajić B, Colella V, et al. Eyeworm infections in dogs and in a human patient in Serbia: a One Health approach is needed. Comp Immunol Microbiol Infect Dis. 2016;45:20-2. http://dx.doi.org/10.1016/j.cimid.2016.01.003

8. Paradžik MT, Samardžić K, Živičnjak T, Martinković F, Janjetović Ž, Miletić-Medved M. Thelazia callipaeda: first human case of thelaziosis in Croatia. Wien Klin Wochenschr 2016;128:221-3. http://dx.doi.org/10.1007/s00508-015-0889-1

9. Otranto D, Lia RP, Traversa D, Giannetto S. Thelazia callipaeda (Spirurida, Thelaziidae) of carnivores and humans: morphological study by light and scanning electron microscopy. Parassitologia. 2003;45:125-33.

10. Otranto D, Testini G, Deluca F, Hu M, Shamsi S, Gasser RB. Analysis of genetic variability within Thelazia callipaeda (Nematoda: Thelazioidea) from Europe and Asia by sequencing and mutation scanning of mitochondrial cytochrome c oxidase subunit 1. Mol Cell Probes. 2005;19:306-13. http://dx.doi.org/10.1016/j.mcp.2005.05.001

Address for correspondence: Domenico Otranto, Università Degli Studi di Bari, Str. Prov. per Casamassima Km 3, 70010 Valenzano, Bari, Italy; email: domenico.otranto@uniba.it

\section{Febrile or Exanthematous Illness Associated with Zika, Dengue, and Chikungunya Viruses, Panama}

\section{Dimelza Araúz, ${ }^{1}$ Luis De Urriola, ${ }^{1}$ José Jones, Marlene Castillo, Alexander Martínez, Edison Murillo, Leonidas Troncoso, María Chen, Leyda Abrego, Blas Armién, Juan M. Pascale, Néstor Sosa, Sandra López-Verges, Brechla Moreno}

Author affiliations: Gorgas Memorial Institute for Health Studies, Panama City, Panama (D. Araúz, M. Castillo, M. Chen, L. Abrego, S. López-Verges, B. Moreno, A. Martinez, B. Armién, J.M. Pascale, N. Sosa); Panama Ministry of Health Department of Epidemiology, Guna Yala, Panama (L. De Urriola); Health Center Guna Yala, Guna Yala (J. Jones, E. Murillo, L. Troncoso)

DOI: http://dx.doi.org/10.3201/eid2208.160292

To the Editor: The earliest clinical cases of Zika virus infection were reported from continental South America in

${ }^{1}$ These authors contributed equally to this article.
2015 (1), after which the virus spread rapidly through the Americas (2). Here we describe an investigation of febrile or exanthematous illnesses for possible association with Zika, dengue, or chikungunya virus; these illnesses occurred in the Guna Yala region of eastern Panama, which borders northern Colombia (Figure).

We collected and analyzed a convenience sample of 276 serum samples and 26 paired urine samples from 276 patients who sought care at clinics in Guna Yala during November 27, 2015-January 22, 2016, for reported fever or rash of $<5$ days' duration in addition to 1 of the following: headache, malaise, arthralgia, myalgia, or conjunctivitis. We also collected data on clinical signs and symptoms, date of illness onset, age, sex, residence, and self-reported status of pregnancy.

At first, we performed real-time reverse transcription PCR (rRT-PCR) tests specific for dengue (3) and chikungunya (4) viruses. However, because all the samples received during the week of November 27 were negative for those viruses and Zika virus was being reported in Colombia as of October 2015, we also tested the samples with a flavivirus-specific rRT-PCR (5), followed by amplicon sequencing; or with an rRT-PCR specific for Zika virus (6).

Of the 276 patients whose samples were tested, 164 $(60 \%)$ were female. A total of $22(8 \%)$ samples were positive for dengue; 2 were positive for chikungunya. Of the remaining 252 patients, 50 (20\%) had $\geq 1$ sample that tested positive for Zika virus (50/252 serum samples, 4/26 paired urine samples). Of these 50 patients, $30(60 \%)$ were female. Most of these patients reported illness onset during December 9-27, 2015 (online Technical Appendix Figure 1, http:// wwwnc.cdc.gov/EID/article/22/8/16-0292-Techapp1.pdf). Zika virus infection affected all age groups (median age 35 $\mathrm{y}$, range $0.1-80 \mathrm{y}$ ).

The most commonly reported signs and symptoms were fever (86\%), exanthema $(72 \%)$, and headache $(62 \%)$. The clinical characteristics of these infections showed no statistically significant difference with those associated with dengue and chikungunya virus infections and with cases found to be negative for all 3 viruses, suggesting that the negative cases could represent Zika virus infections (online Technical Appendix Table). One of the patients with confirmed Zika virus infection reported being in her second trimester of pregnancy; she underwent a fetal ultrasound at 36 weeks' gestation, which was interpreted as normal, and the infant was found to have no neurologic defects at birth.

By using Vero E6 cells (American Type Culture Collection), we isolated $\mathrm{Zika}$ virus from 9 samples (8 serum, 1 urine). Phylogenetic analysis of 5 Zika virus sequences (a 428-nucleotide fragment encompassing a conserved region of the nonstructural protein 5 gene) placed these isolated (GenBank accession nos. KU724096-100) 


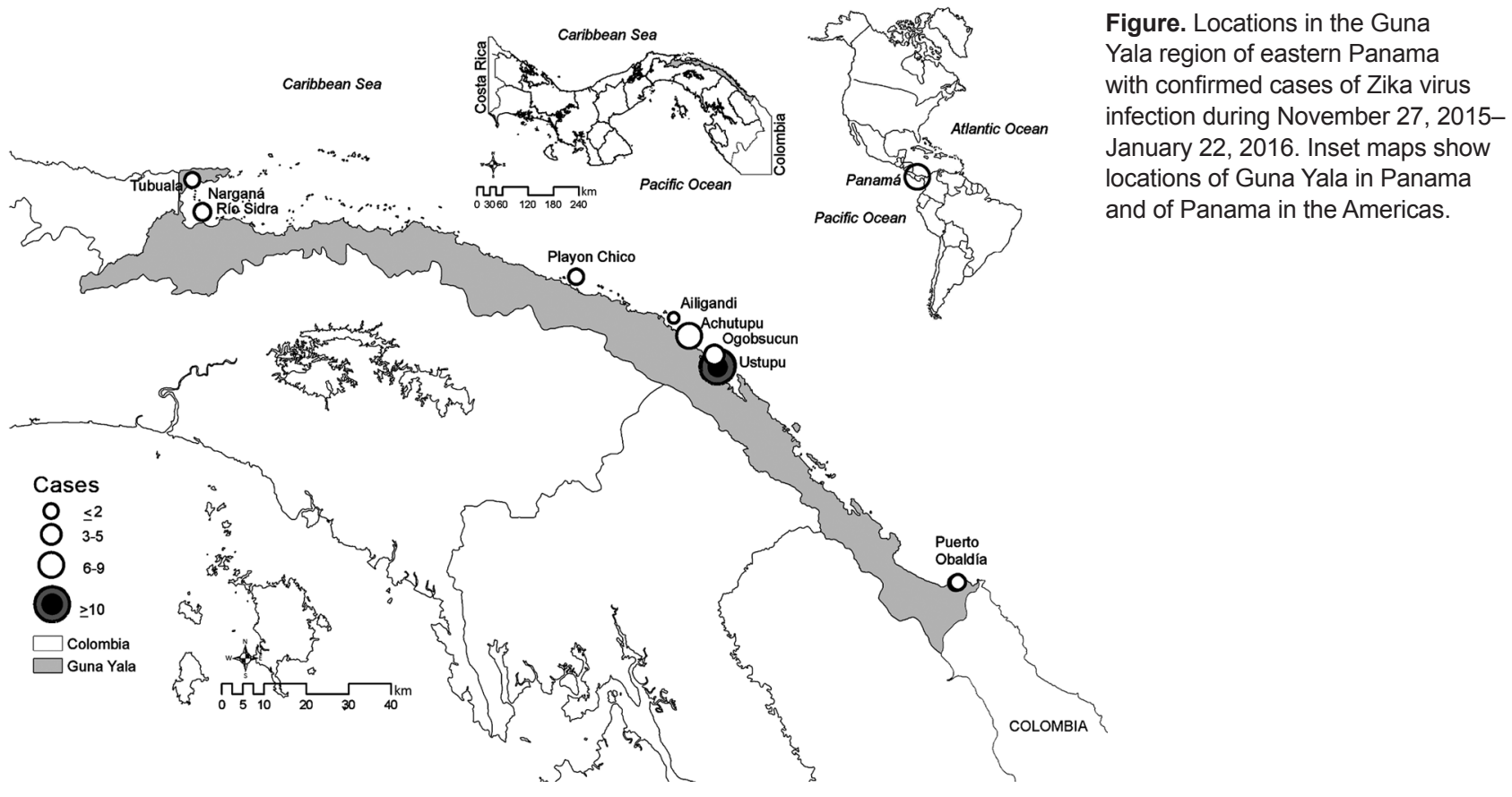

within the Asian lineage, the lineage involved in the spread of Zika virus in the Americas (online Technical Appendix Figure 2) $(2,7)$.

By using molecular methods, we confirmed diagnoses in $27 \%$ of patients during this outbreak. The distribution of positive results suggests that Zika virus was the predominant etiologic virus in this cohort, but we cannot firmly conclude this because most specimens tested negative for Zika, dengue, and chikungunya viruses.

Although results from patient sampling and laboratory testing are not comparable, an assessment in Puerto Rico was able to detect Zika virus RNA by rRT-PCR or IgM by ELISA in $19 \%$ of 155 patients with suspected Zika virus infection (8). Despite the addition of IgM testing, most of the patients whose specimens were tested by rRT-PCR were negative for dengue and Zika viruses.

Several reasons might exist for the high proportion of specimens testing negative for Zika virus. Viremia is often low and short-lived in persons infected with Zika virus (7); the PCR test might not be sensitive enough; some patients with Zika virus infection may have sought care after the virus had been cleared from the blood and urine; our diagnostic capacity was limited by the lack of reliable serologic tests for Zika virus; and we did not test for other viral, bacterial, or parasitic causes of fever or rash illness.

The Panama Ministry of Health is following up with known pregnant women of the Guna Yala region who report Zika virus infection symptoms and is testing urine samples by using Zika virus-specific rRT-PCR within 14 days of symptom onset. Pregnant women confirmed to have Zika virus infection will receive ultrasound monitoring; however, the test has relatively low positive predictive value for detecting microcephaly (9). In Guna Yala, no symptoms of Guillain-Barré syndrome or other neurologic conditions have been detected; however, since January 2016, Zika virus has spread to other regions of Panama, and at least 1 case of Guillain-Barré syndrome has been reported (10). Our experience shows the challenge of diagnosing the causes of fever or rash by using only molecular methods, underscoring the need for diagnostic tools that are rapid and inexpensive but more sensitive and specific.

\section{Acknowledgments}

We thank the personnel of the Panama Ministry of Health for help with the epidemiologic surveillance program, all the personnel of the Gorgas Memorial Institute for Health Studies Department of Research in Virology and Biotechnology for continuous technical support, and Publio González for his assistance with the maps and graphics.

This study was supported by the Gorgas Memorial Institute for Health Studies Department of Research in Virology and Biotechnology and by project 09.044.051 from the Panama Ministry of Economy and Finance (S.L.V.). A.M., B.A., J.M.P., and S.L.V. are members of Sistema Nacional de Investigación (SNI) of the Secretaría Nacional de Ciencia, Tecnología, e Innovación (SENACYT) in Panama.

\section{References}

1. Zanluca C, Melo VC, Mosimann ALP, Santos GI, Santos CN, Luz K. First report of autochthonous transmission of Zika virus in Brazil. Mem Inst Oswaldo Cruz. 2015;110:569-72. http://dx.doi.org/10.1590/0074-02760150192 
2. Hennessey M, Fischer M, Staples JE. Zika virus spreads to new areas-region of the Americas, May 2015-January 2016. MMWR Morb Mortal Wkly Rep. 2016;65:55-8. http://dx.doi.org/10.15585/ mmwr.mm6503e1

3. Lanciotti RS, Calisher CH, Gubler DJ, Chang GJ, Vorndam AV. Rapid detection and typing of dengue viruses from clinical samples by using reverse transcriptase-polymerase chain reaction. J Clin Microbiol. 1992;30:545-51.

4. Lanciotti RS, Kosoy OL, Laven JJ, Panella AJ, Velez JO, Lambert AJ, et al. Chikungunya virus in US travelers returning from India, 2006. Emerg Infect Dis. 2007;13:764-7. http://dx.doi.org/10.3201/eid1305.070015

5. Ayers M, Adachi D, Johnson G, Andonova M, Drebot M, Tellier R. A single tube RT-PCR assay for the detection of mosquito-borne flaviviruses. J Virol Methods. 2006;135:235-9. http://dx.doi.org/10.1016/j.jviromet.2006.03.009

6. Lanciotti RS, Kosoy OL, Laven JJ, Velez JO, Lambert AJ, Johnson AJ, et al. Genetic and serologic properties of Zika virus associated with an epidemic, Yap State, Micronesia, 2007. Emerg Infect Dis. 2008;14:1232-9. http://dx.doi.org/10.3201/ eid1408.080287

7. Lanciotti RS, Lambert AJ, Holodniy M, Saavedra S, Signor LD. Phylogeny of Zika virus in Western Hemisphere, 2015. Emerg Infect Dis. 2016;22:933-5. http://dx.doi.org/10.3201/ eid2205.160065

8. Thomas DL, Sharp TM, Torres J, Armstrong PA, Munoz-Jordan J, Ryff KR, et al. Local transmission of Zika virus-Puerto Rico, November 23, 2015-January 28, 2016. MMWR Morb Mortal Wkly Rep. 2016;65:154-8. http://dx.doi.org/10.15585/mmwr.mm6506e2

9. Leibovitz Z, Daniel-Spiegel E, Malinger G, Haratz K, Tamarkin M, Gindes L, et al. Microcephaly at birth - the accuracy of three references for fetal head circumference. How can we improve prediction? Ultrasound Obstet Gynecol. 2015;2:23. http://dx.doi.org/10.1002/uog.15801

10. World Health Organization. Guillain-Barré syndrome-Panama [cited 2016 Mar 29]. http://www.who.int/csr/don/29-march2016-gbs-panama/en/

Address for correspondence: Brechla Moreno, Instituto Conmemorativo Gorgas de Estudios de la Salud, Ave Justo Arosemena calle 35 y 36, Panama City 0816-02593, Panama; email: bmoreno@gorgas.gob.pa

\section{Influenza D Virus Infection in Herd of Cattle, Japan}

\section{Shin Murakami, Maiko Endoh, Tomoya Kobayashi, Akiko Takenaka-Uema, James K. Chambers, Kazuyuki Uchida, Masugi Nishihara, Benjamin Hause, Taisuke Horimoto}

\author{
Author affiliations: University of Tokyo, Tokyo, Japan \\ (S. Murakami, M. Endoh, T. Kobayashi, A. Takenaka-Uema, \\ J.K. Chambers, K. Uchida, M. Nishihara, T. Horimoto); Kansas \\ State University, Manhattan, Kansas, USA (B. Hause)
}

DOI: http://dx.doi.org/10.3201/eid2208.160362

To the Editor: Although the provisionally named influenza D virus was first isolated as an influenza $\mathrm{C}$-like virus from pigs with respiratory illness in Oklahoma in $2011(1,2)$, epidemiologic analyses suggested that cattle are major reservoirs of this virus (3) and the virus is potentially involved in the bovine respiratory disease complex. The high rates of illness and death related to this disease in feedlot cattle are caused by multiple factors, including several viral and bacterial co-infections. Influenza D viruses were detected in cattle and pigs with respiratory diseases (and in some healthy cattle) in China (4), France (5), Italy (6), among other countries, indicating their wide global geographic distribution. Although the influenza D virus, like the human influenza $\mathrm{C}$ virus, is known to use 9-O-acetylated sialic acids as the cell receptor $(2,7)$, its zoonotic potential is undefined because of limited research $(1,8)$. We report influenza D virus infection in a herd of cattle in Japan.

To determine the presence of influenza D virus, on January 8, 2016, we used hemagglutination inhibition (HI) to test a convenience sample of 28 serum samples from healthy animals in a herd of female cattle in the Ibaraki Prefecture in central Japan. Two viruses with heterologous antigenicities, D/swine/Oklahoma/1334/2011 (D/OK) and D/ bovine/Nebraska/9-5/2012 (D/NE) (9), were used for the assay with receptor-destroying enzyme (Denka: RDE II)treated samples. Eight samples were positive for antibodies against both viruses, with HI titers of 1:80-1:640 for $\mathrm{D} /$ OK and with 2-fold or 4-fold lower HI titers (1:40-1:160) for $\mathrm{D} / \mathrm{NE}$ in each sample, indicating previous infections in these cows, which ranged in age from $\approx 2$ to 9 years. We also detected $\mathrm{HI}$ antibodies in serum samples from other cattle herds in several regions of Japan, although positivity rates varied (T. Horimoto, unpub. data). These data demonstrate the circulation of influenza D virus in Japan, as reported in other countries (3-6), emphasizing that the virus could be distributed worldwide.

Because 4 of the tested cows showed mild respiratory illness in January, we collected serum samples from the same 28 cows on February 3. At that time, only 1 cow still showed clinical signs; we collected a nasal swab sample from this cow. HI testing revealed that, of the 20 cows that had negative results in the first round of testing, 19 were positive for both $\mathrm{D} / \mathrm{OK}$ and $\mathrm{D} / \mathrm{NE}$ on the second test, which strongly confirms that influenza D virus infection had occurred and readily spread in this herd during January. However, most cows seemed to be subclinically infected with the virus. We cannot exclude the possibility of influenza $\mathrm{D}$ virus being a co-factor in causing respiratory illness because we did not evaluate the role of other viruses and bacteria in disease progression. HI titers (range 1:40-1:320) for D/NE were the same as or only 2 times lower than those for $\mathrm{D} / \mathrm{OK}$ in all seroconversion samples, unlike the results for the seropositive samples in the first testing (online Technical Appendix, http://wwwnc.cdc.gov/ 